\title{
Ammonium in Nutrient Solutions Decreases Free Chlorine Concentration from Sodium Hypochlorite
}

\author{
Dustin P. Meador and Paul R. Fisher ${ }^{1}$ \\ Department of Environmental Horticulture, University of Florida, IFAS, \\ 1549 Fifield Hall, P.O. Box 110670, Gainesville, FL 32611
}

Additional index words. chlorine demand, disinfestation, fertilizer, sanitation, water treatment

\begin{abstract}
The objective was to quantify the effect of water-soluble fertilizers on concentration of free chlorine level in a sodium hypochlorite solution. Research on the disinfestation strength and phytotoxicity risk of chlorine compounds is needed, because control of waterborne pathogens has been based on response to free chlorine, whereas dual injection of fertilizer and chlorine is a common horticultural practice. Free chlorine from sodium hypochlorite was applied at $2.6 \mathrm{mg} \cdot \mathrm{L}^{-1}$ chlorine $(\mathrm{CI})$ to deionized water only (control) or deionized water with 11 nutrient solutions at $200 \mathrm{mg} \cdot \mathrm{L}^{-1}$ nitrogen $(\mathrm{N})$. Nutrient solutions included reagent-grade ammonium sulfate $\left(\mathrm{NH}_{4}\right)_{2} \mathrm{SO}_{4}$, ammonium nitrate $\left(\mathrm{NH}_{4} \mathrm{NO}_{3}\right)$, potassium nitrate $\left(\mathrm{KNO}_{3}\right)$, and urea salts and seven commercial blended $\mathrm{N}-\mathrm{P}-\mathrm{K}$ water-soluble fertilizers that contained both macro- and micronutrients. Commercial fertilizers contained ammonium-N at $0 \%$ to $50 \%$ of total-N, urea-N at $0 \%$ to $14 \%$ of total-N, and nitrate-N at $50 \%$ to $93 \%$ of total-N. Free $\mathrm{Cl}\left(\mathrm{mg} \cdot \mathrm{L}^{-1}\right)$, total $\mathrm{Cl}\left(\mathrm{mg} \cdot \mathrm{L}^{-1}\right)$, and oxidation-reduction potential (ORP, in $\mathrm{mV}$ ) were measured $2 \mathrm{~min}$ and 60 min after $\mathrm{Cl}$ was applied. Combined $\mathrm{Cl}$ was calculated as the difference between the total and free $\mathrm{Cl}$ measurements. All solutions were maintained at $\mathrm{pH} 6$ and $25^{\circ} \mathrm{C}$. In the control solution, free $\mathrm{Cl}$ was $2.6 \mathrm{mg} \cdot \mathrm{L}^{-1}$ after 2 minutes and decreased to $2.2 \mathrm{mg} \cdot \mathrm{L}^{-1}$ after 60 minutes. The ammonium-containing solutions $\left(\mathrm{NH}_{4}\right)_{2} \mathrm{SO}_{4}$ and $\mathrm{NH}_{4} \mathrm{NO}_{3}$ resulted in free $\mathrm{Cl}$ below $0.1 \mathrm{mg} \cdot \mathrm{L}^{-1}$ after 2 minutes. Urea reacted more slowly than ammonium salts, whereby free $\mathrm{Cl}$ decreased to $2.3 \mathrm{mg} \cdot \mathrm{L}^{-1}$ after 2 minutes and $0.4 \mathrm{mg} \cdot \mathrm{L}^{-1}$ after 60 minutes. In contrast, $\mathrm{KNO}_{3}$ had less impact on free $\mathrm{Cl}$ with $2.4 \mathrm{mg} \cdot \mathrm{L}^{-1}$ free $\mathrm{Cl}$ available at both 2 minutes and 60 minutes. With all commercial fertilizers tested, free $\mathrm{Cl}$ decreased after 2 minutes to below $0.1 \mathrm{mg} \cdot \mathrm{L}^{-1}$. Total $\mathrm{Cl}$ remained above $2 \mathrm{mg} \cdot \mathrm{L}^{-1}$ after 60 minutes in all treatments, indicating that the majority of $\mathrm{Cl}$ was in a combined form for ammonium and urea salts and commercial fertilizers. The ORP of commercial fertilizer blends and ammonium-containing salts was lower than $600 \mathrm{mV}$, whereas deionized water, $\mathrm{KNO}_{3}$, and urea treatments had ORP levels above $650 \mathrm{mV}$. Nutrient solutions containing ammonium or urea required $20 \mathrm{mg} \cdot \mathrm{L}^{-1}$ or more of applied $\mathrm{Cl}$ to provide residual free $\mathrm{Cl}$ above $2 \mathrm{mg} \cdot \mathrm{L}^{-1}$ at 2 minutes.
\end{abstract}

Chlorine from calcium hypochlorite, sodium hypochlorite, or $\mathrm{Cl}$ gas sources has complex chemistry in irrigation water. Once added to water, $\mathrm{Cl}$ is converted to hypochlorite $\left(\mathrm{OCl}^{-}\right)$and hypochlorous acid $(\mathrm{HOCl})$, which along with dissolved $\mathrm{Cl}$ gas are collectively termed free $\mathrm{Cl}$. The balance between hypochlorous acid and hypochlorite is pH-dependent, whereby hypochlorous acid predominates at solution $\mathrm{pH}$ below 7.5 or hypochlorite ions above pH 7.5 (Morris, 1966). Water $\mathrm{pH}$ also influences the sanitizing strength

Received for publication 15 Apr. 2013. Accepted for publication 12 Aug. 2013

We thank the USDA-ARS Floriculture and Nursery Research Initiative and industry partners of the Floriculture Research Alliance at the University of Florida (floriculturealliance.org) and Water Education Alliance for Horticulture (watereducationalliance.org) for supporting this research. We also thank Charles Guy, Philip Harmon, Natalia Peres, Rosa Raudales, and Max Teplitski from the University of Florida for their scientific contributions. ${ }^{1}$ To whom reprint requests should be addressed; e-mail pfisher@ufl.edu.
ORP and control of coliform bacteria by chlorination of wastewater ( $\mathrm{Yu}$ et al., 2008). Coliforms and pathogenic bacteria were rapidly controlled in post-harvest wash water if ORP was maintained between 650 and 700 $\mathrm{mV}$ (Suslow, 2004). Lang et al. (2008) found that Pythium aphanidermatum and P. dissotocum zoospores were killed within 0.25 to $0.5 \mathrm{~min}$ when ORP was above $780 \mathrm{mV}$ in chlorinated water.

In the presence of organic and inorganic $\mathrm{N}$ including ammonia, a range of equilibria reactions occur to form "complexed" chlorinated molecules such as chloramines in equations [ 1 to 3 ] adapted from the U.S. Environmental Protection Agency (EPA, 1999). The concentration of both free $\mathrm{Cl}$ and complexed $\mathrm{Cl}$ together make up the concentration of "total" $\mathrm{Cl}$.

$$
\begin{aligned}
\mathrm{NH}_{3}+\mathrm{HOCl} \rightleftharpoons & \mathrm{NH}_{2} \mathrm{Cl}(\text { monochloramine }) \\
& +\mathrm{H}_{2} \mathrm{O}
\end{aligned}
$$

$$
\left.\mathrm{NH}_{2} \mathrm{Cl}+\mathrm{HOCl} \rightleftharpoons \mathrm{NHCl}_{2} \text { (dichloramine }\right)
$$$$
+\mathrm{H}_{2} \mathrm{O}
$$

$$
\begin{aligned}
\mathrm{NHCl}_{2}+\mathrm{HOCl} \rightleftharpoons & \mathrm{NCl}_{3}(\text { trichloramine }) \\
& +\mathrm{H}_{2} \mathrm{O}
\end{aligned}
$$

In municipal water treatment facilities, a dose of one part of inorganic $\mathrm{N}$ to every three parts of free $\mathrm{Cl}$ reportedly results in $99 \%$ conversion of free $\mathrm{Cl}$ to chloramines after $0.2 \mathrm{~s}$ at $\mathrm{pH} 7$ or $147 \mathrm{~s}$ at $\mathrm{pH} 4$ (White, 1992). In horticulture irrigation, water-soluble fertilizer containing ammonium, nitrate, and/or urea $\mathrm{N}$ is often supplied in irrigation between 100 and $200 \mathrm{mg} \cdot \mathrm{L}^{-1}$ total $\mathrm{N}$ and then treated with free $\mathrm{Cl}$ concentrations between 1 and 2 $\mathrm{mg} \cdot \mathrm{L}^{-1} \mathrm{Cl}$. With such a high $\mathrm{N}$ to $\mathrm{Cl}$ ratio, the majority of free $\mathrm{Cl}$ would therefore be expected to rapidly convert to chlorinated $\mathrm{N}$ forms. Chlorine also reacts with urea, although the chain of reactions is more complex and slow-acting than chlorination of ammonia (Blatchley and Cheng, 2010).

Chloramines are considered weaker sanitizers than free $\mathrm{Cl}$ from hypochlorous acid (White, 1992) because of the longer contact time that chloramines require to control human pathogens compared with an equal concentration of free $\mathrm{Cl}$. Control of $99 \%$ of Escherichia coli with hypochlorous acid at $1 \mathrm{mg} \cdot \mathrm{L}^{-1} \mathrm{Cl}$ required a 1 -min contact time, whereas with combined $\mathrm{Cl}$ forms including $\mathrm{NH}_{2} \mathrm{Cl}$ and $\mathrm{NHCl}_{2}$ at $1 \mathrm{mg} \cdot \mathrm{L}^{-1} \mathrm{Cl}$ required more than 100 min (Akin et al., 1982). However, the greater stability of chloramines in the presence of organic compounds compared with hypochlorous acid may increase penetration of chloramines into biofilm, resulting is greater inactivation of biofilm bacteria (LeChevallier et al., 1988). The American Water Works Association (AWWA, 1991) provided guidelines for residual concentration of between 0.5 to $1 \mathrm{mg} \cdot \mathrm{L}^{-1}$ chloramine for disinfection of groundwater (White, 1992) 
Table 1. Nutrient concentrations used in the study (reported by manufacturer) on a percentage by mass for individual nutrients.

\begin{tabular}{|c|c|c|c|c|c|c|c|c|c|c|c|c|c|c|c|c|c|}
\hline Fertilizer $(\mathrm{N}-\mathrm{P}-\mathrm{K})$ & Source $^{z}$ & $\begin{array}{l}\mathrm{CaCO}_{3} \\
\text { equiv. }\end{array}$ & $\begin{array}{l}\text { Acid base } \\
(\mathrm{A} / \mathrm{B})^{\mathrm{x}}\end{array}$ & $\mathrm{NH}_{4}-\mathrm{N}$ & $\mathrm{NO}_{3}-\mathrm{N}$ & Urea-N & $\mathrm{P}$ & $\mathrm{K}$ & $\mathrm{Ca}$ & $\mathrm{Mg}$ & $\mathrm{S}$ & B & $\mathrm{Cu}$ & $\mathrm{Fe}$ & $\mathrm{Mn}$ & Mo & $\mathrm{Zn}$ \\
\hline $\mathrm{N} 15-2.2 \mathrm{P}-12.5 \mathrm{~K}$ & $\mathrm{E}$ & 65 & B & 1.1 & 11.8 & 2.1 & 2.2 & 12.5 & 5.0 & 2.0 & 0.0 & 0.02 & 0.02 & 0.07 & 0.04 & 0.01 & 0.04 \\
\hline $\mathrm{N} 14-1.8 \mathrm{P}-11.6 \mathrm{~K}$ & G & 100 & B & 2.0 & 12.0 & 0.0 & 1.8 & 11.6 & 5.0 & 2.0 & 0.0 & 0.02 & 0.02 & 0.07 & 0.03 & 0.01 & 0.03 \\
\hline $\mathrm{N} 15-2.2 \mathrm{P}-16.6 \mathrm{~K}$ & $\mathrm{E}$ & 24 & A & 4.3 & 10.7 & 0.0 & 2.2 & 20.8 & 0.0 & 2.5 & 1.0 & 0.01 & 0.02 & 0.07 & 0.04 & 0.07 & 0.04 \\
\hline $\mathrm{N} 20-0.9 \mathrm{P}-16.6 \mathrm{~K}$ & $\mathrm{E}$ & 145 & A & 7.2 & 12.8 & 0.0 & 0.9 & 16.6 & 0.0 & 1.1 & 0.7 & 0.02 & 0.02 & 0.10 & 0.05 & 0.01 & 0.05 \\
\hline N19-5.6P-19.4K & G & 340 & A & 9.7 & 9.7 & 0.0 & 2.5 & 16.1 & 0.0 & 0.0 & 0.0 & 0.02 & 0.02 & 0.10 & 0.05 & 0.01 & 0.05 \\
\hline Ammonium sulfate & Reagent & & & 20.8 & 0.0 & 0.0 & 0.0 & 0.0 & 0.0 & 0.0 & 23.8 & & & & & & \\
\hline Ammonium nitrate & Reagent & & & 17.2 & 17.2 & 0.0 & 0.0 & 0.0 & 0.0 & 0.0 & 0.0 & & & & & & \\
\hline
\end{tabular}

${ }^{\mathrm{z}} \mathrm{G}=$ Greencare Fertilizers; $\mathrm{E}=$ Everris Co.

${ }^{\mathrm{y}}$ Reported kg/metric ton.

${ }^{x}$ Potential acidity or basicity.

such as from wells or irrigation catchment areas. Based on experience with control of human pathogens in water supply, irrigation of edible crops with complexed $\mathrm{Cl}$ is likely to require longer contact times and/or higher total $\mathrm{Cl}$ application concentrations compared with free $\mathrm{Cl}$ for control of human pathogens. However, data are not available for plant pathogens.

There are limited research data on the residual level of free or total $\mathrm{Cl}$ in the presence of nutrient solutions despite the common practice of dual injection of $\mathrm{Cl}$ and watersoluble fertilizer and the potential impact on pathogen control. The research objective of this study was to determine the free and total $\mathrm{Cl}$ and ORP responses over time when nutrient solutions were blended with sodium hypochlorite.

\section{Materials and Methods}

Three experiments were run: Expt. 1, multiple fertilizers, $200 \mathrm{mg} \cdot \mathrm{L}^{-1} \mathrm{~N}$ from seven commercial blended fertilizers containing macro- and micronutrients and reagent-grade nutrient solutions were mixed with $2.6 \mathrm{mg} \cdot \mathrm{L}^{-1}$ $\mathrm{Cl}$ from sodium hypochlorite. In Expt. 2, multiple $\mathrm{N}$ concentrations, five concentrations of $\mathrm{N}$ from 0 to $600 \mathrm{mg} \cdot \mathrm{L}^{-1}$ from four reagent-grade nutrient solutions were mixed with $2.6 \mathrm{mg} \cdot \mathrm{L}^{-1} \mathrm{Cl}$. Expt. 3 high applied $\mathrm{Cl}$ quantified whether 10 or $20 \mathrm{mg} \cdot \mathrm{L}^{-1}$ applied $\mathrm{Cl}$ was sufficient to provide a residual of $2 \mathrm{mg} \cdot \mathrm{L}^{-1} \mathrm{Cl}$ after a 2 -min contact time in the presence of $200 \mathrm{mg} \cdot \mathrm{L}^{-1} \mathrm{~N}$ from commercial fertilizers and reagent-grade $\mathrm{N}$ salts.

The 11 nutrient solutions for Expt. 1 multiple fertilizers are shown in Table 1. Nutrient solutions ranged in the contribution of ammonium, nitrate, and urea to total $\mathrm{N}$ as well as presence of other macro- and micronutrients (Fig. 1). Both commercial blended fertilizers and reagent-grade salts were tested along with deionized water as the control. Fertilizers were sourced from two different manufacturers, Greencare Fertilizers (Kankakee, IL) and Everiss NA, Inc. (Dublin, OH). All commercial fertilizer blends tested contained some ammonium or urea, including high nitrate fertilizer such as $13 \mathrm{~N}-0.9 \mathrm{P}-10.8 \mathrm{~K}$ (Fig. 1).

In Expt. 2 multiple $\mathrm{N}$ concentrations, the four reagent-grade salts from Table 1 were
A

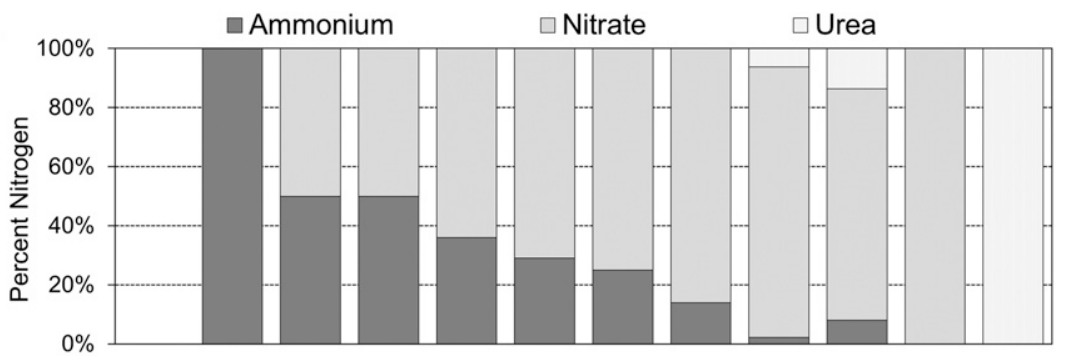

B

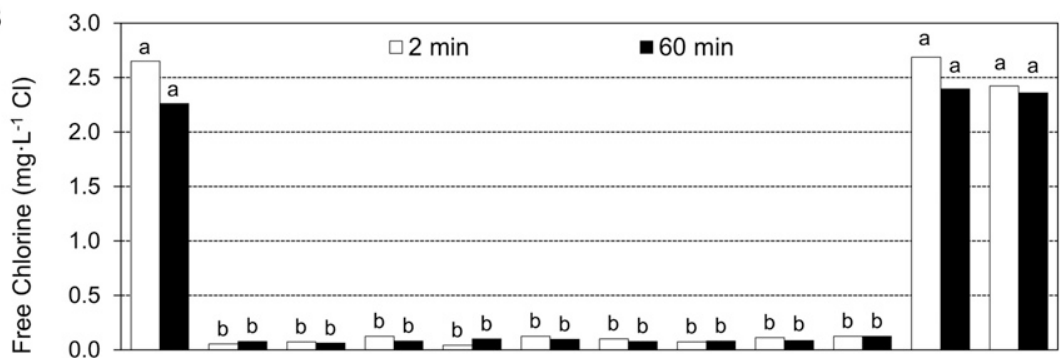

C

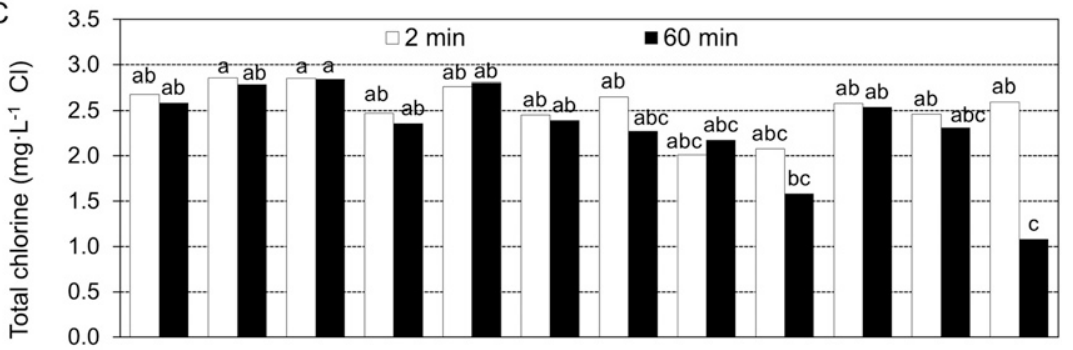

D

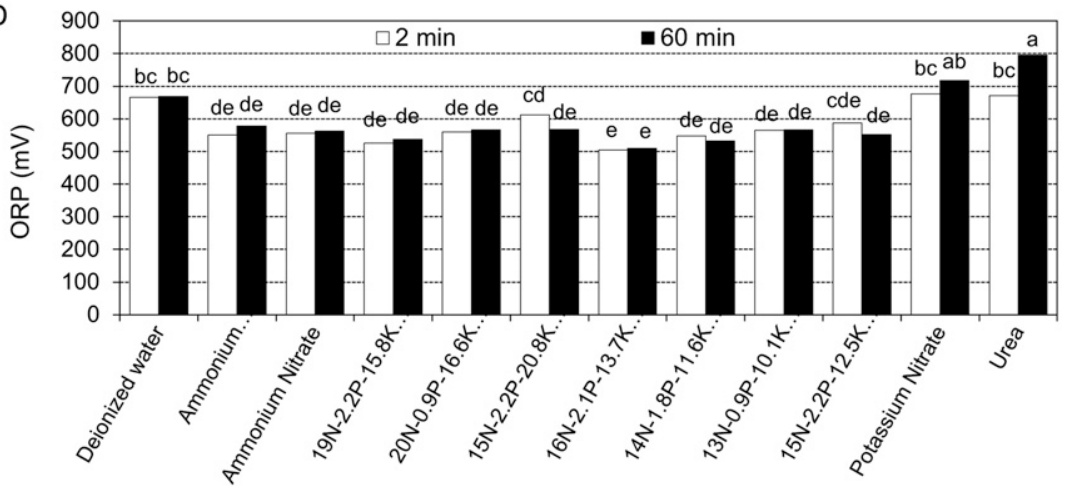

Fig. 1. Nitrogen (N) source and its effect on free and total chlorine and oxidation-reduction potential (ORP) in Expt. 1 multiple fertilizers. A shows the percent contribution of ammonium, nitrate, or urea to total nitrogen in each nutrient source. B-D show the effect of $200 \mathrm{mg} \cdot \mathrm{L}^{-1} \mathrm{~N}$ from commercial fertilizer blends and reagent-grade nutrient solutions on $(\mathbf{B})$ free chlorine $(\mathrm{Cl}),(\mathbf{C})$ total $\mathrm{Cl}$, and (D) ORP after injecting sodium hypochlorite at $2.6 \mathrm{mg} \cdot \mathrm{L}^{-1} \mathrm{Cl}$ and measured after $2 \mathrm{~min}$ and $60 \mathrm{~min}$ contact times. Letters represent mean comparisons using Tukey's honestly significant difference at the $P=0.05$ level for the interaction of nutrient source and measurement time, $n=3$ replicates. 
applied at five $\mathrm{N}$ concentrations $(0,75,150$, 300 , and $600 \mathrm{mg} \cdot \mathrm{L}^{-1} \mathrm{~N}$ ) in combination with $2.6 \mathrm{mg} \cdot \mathrm{L}^{-1} \mathrm{Cl}$. In Expt. 3 high applied $\mathrm{Cl}, \mathrm{Cl}$ was applied at 10 or $20 \mathrm{mg} \cdot \mathrm{L}^{-1} \mathrm{Cl}$ from sodium hypochlorite to the fertilizer treatments in Table 1 at $200 \mathrm{mg} \cdot \mathrm{L}^{-1} \mathrm{~N}$. Expt. 3 was analyzed separately from Expt. 1 despite a similar experimental design, because the procedure was run at a different time, dilution of the samples was necessary when analyzing higher levels of free and total $\mathrm{Cl}$ levels in Expt. 3, to provide in-range concentrations for measurement, and measurements were made at 2 min only. No sample dilution was required for Expt. 1.

Nutrient solutions were prepared in a closed system in 4-L plastic containers in all experiments. Nutrient solutions were adjusted to $\mathrm{pH} 6.0$ using $\mathrm{KOH}$ or $\mathrm{H}_{2} \mathrm{SO}_{4}$ with constant mixing and were maintained at $25^{\circ} \mathrm{C}$. Chlorine solution was prepared by adding Clorox Regular-Bleach $(6.15 \%$ sodium hypochlorite) (Clorox Company, Oakland, $\mathrm{CA})$ to deionized water and then injecting sufficient solution into the closed nutrient solution container through a septum to provide a final concentration of $2.6 \mathrm{mg} \cdot \mathrm{L}^{-1} \mathrm{Cl}$ for Expts. 1 and 2 and 2.6, 10, or $20 \mathrm{mg} \cdot \mathrm{L}^{-1} \mathrm{Cl}$ in Expt. 3.

Free and total $\mathrm{Cl}, \mathrm{pH}$, temperature, and ORP were measured in the nutrient solution before addition of $\mathrm{Cl}$ and 2 and $60 \mathrm{~min}$ after addition of $\mathrm{Cl}$. Free and total $\mathrm{Cl}$ concentrations were measured as described by methods

Table 2. Analysis of variance summary for Expt. 1 multiple nitrogen $(\mathrm{N})$ sources, where free chlorine (Cl) was applied to 11 nutrient solutions at $200 \mathrm{mg} \cdot \mathrm{L}^{-1} \mathrm{~N}$ and a deionized water control ( $\mathrm{N}$ source) at $2.6 \mathrm{mg} \cdot \mathrm{L}^{-1} \mathrm{Cl}$ with $2 \mathrm{~min}$ and 60 min contact times (Time). ${ }^{\mathrm{z}}$

\begin{tabular}{lccc}
\hline & $\begin{array}{c}\text { Free Cl } \\
\left(\mathrm{mg} \cdot \mathrm{L}^{-1}\right)\end{array}$ & $\begin{array}{c}\text { ORP } \\
(\mathrm{mV})\end{array}$ & $\begin{array}{c}\text { Total } \\
\mathrm{Cl}\left(\mathrm{mg} \cdot \mathrm{L}^{-1}\right)\end{array}$ \\
\hline N source & $* * *$ & $* * *$ & $* * *$ \\
Time & NS & NS & $*$ \\
N source $\times$ time & NS & $* *$ & NS \\
Block & NS & NS & $* * *$ \\
\hline
\end{tabular}

${ }^{\mathrm{z}}$ The block was the measurement day $(\mathrm{n}=3)$. NS $=$ not significant, ${ }^{*} P<0.05,{ }^{* *} P<0.01,{ }^{* * *} P<$ 0.001 .

$\mathrm{ORP}=$ oxidation-reduction potential.

Table 3. Analysis of variance summary for Expt. 2 multiple nitrogen $(\mathrm{N})$ concentrations where free chlorine $(\mathrm{Cl})$ was applied at $2.6 \mathrm{mg} \cdot \mathrm{L}^{-1}$ $\mathrm{Cl}$ to four reagent nutrient solutions ( $\mathrm{N}$ source) at six concentrations from 0 to $600 \mathrm{mg} \cdot \mathrm{L}^{-1} \mathrm{~N}$ ([N]) with 2- or 60-min contact time (Time). ${ }^{\mathrm{z}}$

\begin{tabular}{lccc}
\hline & $\begin{array}{c}\text { Free Cl } \\
\left(\mathrm{mg} \cdot \mathrm{L}^{-1}\right)\end{array}$ & $\begin{array}{c}\text { ORP } \\
(\mathrm{mV})\end{array}$ & $\begin{array}{c}\text { Total Cl } \\
\left(\mathrm{mg} \cdot \mathrm{L}^{-1}\right)\end{array}$ \\
\hline $\mathrm{N}$ source & $* * *$ & $* * *$ & $* * *$ \\
{$[\mathrm{~N}]$} & $* * *$ & $* * *$ & $* * *$ \\
Time & $\mathrm{NS}$ & $* * *$ & $* * *$ \\
N source $\times$ time & $*$ & $* * *$ & $* * *$ \\
$\mathrm{~N}$ source $\times[\mathrm{N}]$ & $* * *$ & $* * *$ & $* * *$ \\
Time $\times[\mathrm{N}]$ & $\mathrm{NS}$ & $\mathrm{NS}$ & $* * *$ \\
$\mathrm{~N}$ source $\times$ time $\times[\mathrm{N}]$ & $\mathrm{NS}$ & $* * *$ & $* * *$ \\
Block & $\mathrm{NS}$ & $\mathrm{NS}$ & $\mathrm{NS}$ \\
\hline
\end{tabular}

${ }^{\mathrm{z}}$ The block was the measurement day $(\mathrm{n}=3)$. NS $=$ not significant, ${ }^{*} P<0.05, * * P<0.01, * * * P<$ 0.001 .
$2350 \mathrm{~B}$ and $4500 \mathrm{Cl}$. F. 1d, respectively (American Public Health Association, 1995). Colorimetric determination of $\mathrm{mg} \cdot \mathrm{L}^{-1} \mathrm{Cl}$ was performed using a Thermo Scientific Orion AQUAfast IV ${ }^{\circledR}$ AQ4000 colorimeter, AC4P71 Chlorine Free and Chlorine Total reagentpacks (Thermo-Fisher, Barrington, IL). Solution $\mathrm{pH}$ was measured using an Orion Model 61-65 (Thermo-Fisher), solid-state probe and ORP measured using an Orion 91-79 Triode electrode and both $\mathrm{pH}$ and ORP were displayed simultaneously on a FourStar meter (Thermo-Fisher).

In each experiment, the design was a randomized complete block design. On each day (block), a single replicate of each combined nutrient and chlorine treatment was run in random order. There were three blocks (days) for Expts. 1 and 2 and two blocks (days) for Expt. 3. For all experiments, data were analyzed using analysis of variance with SAS PROC GLM (SAS Version 9.1; SAS Institute, Cary, NC). Means were separated using Tukey's honestly significant difference test at the $P \leq 0.05$ level.

\section{Results and Discussion}

In Expt. 1 multiple fertilizers, there was a significant $(P \leq 0.001)$ main effect of $\mathrm{N}$ source on the concentration of free $\mathrm{Cl}$, ORP, and total $\mathrm{Cl}$ (Table 2), and time (2 or $60 \mathrm{~min}$ ) affected total $\mathrm{Cl}(P \leq 0.05)$. With total $\mathrm{Cl}$ measurements there was a significant $(P \leq$ $0.001)$ block effect of the measurement day. There was a two-way interaction $(P \leq 0.001)$ of $\mathrm{N}$ source and time for measured ORP.

Control solutions of deionized water did not differ in measured variables between 2 min and $60 \mathrm{~min}$ (Fig. 1). At $2 \mathrm{~min}$, free $\mathrm{Cl}$ $\left(2.6 \mathrm{mg} \cdot \mathrm{L}^{-1} \mathrm{Cl}\right)$ in the control was higher than the free $\mathrm{Cl}$ concentration measured in all nutrient solutions containing commercial blended fertilizer, which was below the minimum reportable limit $\left(0.15 \mathrm{mg} \cdot \mathrm{L}^{-1} \mathrm{Cl}\right)$ of the colorimeter. Commercial blended fertilizers had less effect on total $\mathrm{Cl}$ than on free $\mathrm{Cl}$. The ORP was lower in most commercial blended fertilizers compared with the control at both 2 and $60 \mathrm{~min}$, regardless of the proportion of each $\mathrm{N}$ form.

Potassium nitrate and urea had free $\mathrm{Cl}$ concentration equal to the control at $2 \mathrm{~min}$ and $60 \mathrm{~min}$, whereas with ammonium nitrate and ammonium sulfate, the free $\mathrm{Cl}$ concentrations were below the $0.15-\mathrm{mg} \cdot \mathrm{L}^{-1} \mathrm{Cl}$ detectable limit of the meter. The ORP was higher in potassium nitrate than ammonium nitrate and ammonium sulfate and was equal to the ORP of the control. The free $\mathrm{Cl}$ concentration measured in the urea solution was higher than the total $\mathrm{Cl}$ at $60 \mathrm{~min}$. Therefore, estimation of total and/or free $\mathrm{Cl}$ in solutions containing urea was not accurate because free $\mathrm{Cl}$ forms (hypochlorous acid, hypochlorite, and dissolved $\mathrm{Cl}$ ) are components of total $\mathrm{Cl}$, and free $\mathrm{Cl}$ should therefore be equal to or lower than total $\mathrm{Cl}$. Urea had a higher ORP than any other solution at $60 \mathrm{~min}$, emphasizing the complexity of reactions between $\mathrm{Cl}$ and urea (Blatchley and Cheng, 2010).

In Expt. 2 multiple $\mathrm{N}$ concentrations, there were significant interactions between reagent-grade $\mathrm{N}$ sources, concentration, and time (Table 3). There was no difference in the free $\mathrm{Cl}$ concentration for the control between 2 and 60 min (Fig. 2). Among the reagents, the higher level of free $\mathrm{Cl}$ was measured in nutrient solutions with potassium nitrate than urea. The lowest free $\mathrm{Cl}$ levels occurred in ammonium nitrate or ammonium sulfate at 75 to $600 \mathrm{mg} \cdot \mathrm{L}^{-1} \mathrm{~N}$. Free $\mathrm{Cl}$ level did not
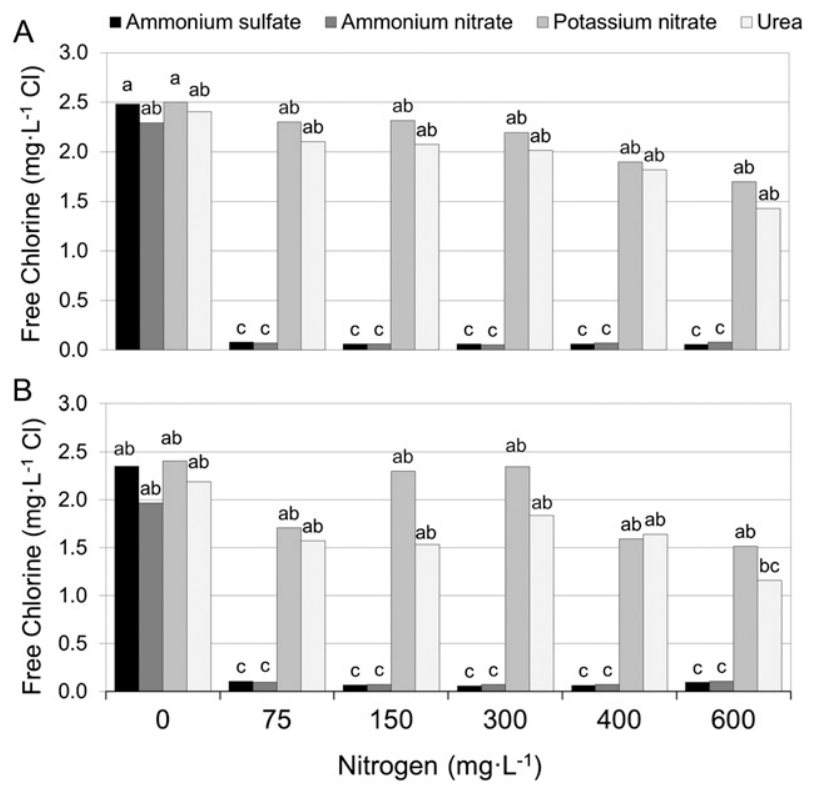

Fig. 2. Effect of nitrogen $(\mathrm{N})$ concentration from four reagent-grade $\mathrm{N}$ sources on free chlorine $(\mathrm{Cl})$ after injecting sodium hypochlorite at $2.6 \mathrm{mg} \cdot \mathrm{L}^{-1} \mathrm{Cl}$ in Expt. 2 multiple $\mathrm{N}$ concentrations, measured after (A) $2 \mathrm{~min}$ and (B) $60 \mathrm{~min}$. Letters represent mean comparisons using Tukey's honestly significant difference at the $P=0.05$ level within each measurement time, $\mathrm{n}=3$ replicates. 
decline significantly compared with the control for potassium nitrate or urea at 75 to $600 \mathrm{mg} \cdot \mathrm{L}^{-1} \mathrm{~N}$.

In Expt. 3 high applied $\mathrm{Cl}$, there were significant main and interaction effects of $\mathrm{N}$ source and applied $\mathrm{Cl}$ concentration $(P \leq$ 0.001; Table 4). Free $\mathrm{Cl}$ concentrations for the control at 10 or $20 \mathrm{mg} \cdot \mathrm{L}^{-1}$ applied $\mathrm{Cl}$ were significantly different $\left(9.9\right.$ and $19.9 \mathrm{mg} \cdot \mathrm{L}^{-1}$ $\mathrm{Cl}$, respectively; Fig. 3). At both applied $\mathrm{Cl}$ concentrations, ammonium sulfate and ammonium nitrate, and all commercial fertilizer blends resulted in the same free $\mathrm{Cl}$ level, ranging from 0.20 to $1.26 \mathrm{mg} \cdot \mathrm{L}^{-1} \mathrm{Cl}$. For urea tion was not significantly different from the control at both applied $\mathrm{Cl}$ concentrations.

The decrease in free $\mathrm{Cl}$ levels observed with reagent-grade salts and commercial fertilizer blends in these experiments has practical implications for combining fertilization and water sanitation in horticulture. Where ammonium was present in the solution, the majority of $\mathrm{Cl}$ is likely to be complexed, even at low concentrations (for example, $37.5 \mathrm{mg} \cdot \mathrm{L}^{-1}$ $\mathrm{NH}_{4}-\mathrm{N}$ from ammonium nitrate applied at $75 \mathrm{mg} \cdot \mathrm{L}^{-1} \mathrm{~N}$; Fig. 2). Most commercial fertilizers contain some ammonium, including ammonium sulfate, ammonium phosphate, ammonium nitrate, or as a component in calcium nitrate fertilizer. Nitrate did not decrease free $\mathrm{Cl}$ concentration, and urea reacted slowly, indicating these $\mathrm{N}$ forms would be more compatible with free $\mathrm{Cl}$ than

Table 4. Analysis of variance summary for Expt. 3 high applied chlorine $(\mathrm{Cl})$ where free $\mathrm{Cl}$ was applied at two concentrations of 10 or 20 $\mathrm{mg} \cdot \mathrm{L}^{-1} \mathrm{Cl}([\mathrm{Cl}])$ to 11 nutrient solutions at $200 \mathrm{mg} \cdot \mathrm{L}^{-1}$ nitrogen $(\mathrm{N})$ and a deionized control ( $\mathrm{N}$ source) and free $\mathrm{Cl}$ was measured after 2-min contact time. ${ }^{\mathrm{z}}$

\begin{tabular}{lc}
\hline & Free $\mathrm{Cl}\left(\mathrm{mg} \cdot \mathrm{L}^{-1}\right)$ \\
\hline $\mathrm{N}$ source & $* * *$ \\
{$[\mathrm{Cl}]$} & $* * *$ \\
$\mathrm{~N}$ source $\times[\mathrm{Cl}]$ & $* * *$ \\
Block & $\mathrm{NS}$ \\
\hline zThe block was the measurement day $(\mathrm{n}=2)$. \\
NS = not significant, ${ }^{*} P<0.05, * * P<0.01, * * * P<$ \\
0.001.
\end{tabular}
and potassium nitrate, the free $\mathrm{Cl}$ concentra-

ammonium. Another management strategy would be to use holding tanks to inject $\mathrm{Cl}$ into unfertilized water to provide adequate contact time before injecting fertilizer. A further option to reduce $\mathrm{Cl}$ demand of fertilizer would be to apply granular or controlledrelease fertilizer directly to the growing substrate rather than water-soluble fertilizer.

In the presence of ammonium, high applied concentration of $\mathrm{Cl}$ would be required to achieve residual free $\mathrm{Cl}$ for control of plant pathogens. Even at $20 \mathrm{mg} \cdot \mathrm{L}^{-1} \mathrm{Cl}$ applied free $\mathrm{Cl}$ in Expt. 3, in the presence of ammonium $\mathrm{N}$, the level of free $\mathrm{Cl}$ rapidly decreased to 1.26 or less $\mathrm{mg} \cdot \mathrm{L}^{-1} \mathrm{Cl}$. Given that as high as $2 \mathrm{mg} \cdot \mathrm{L}^{-1}$ of free $\mathrm{Cl}$ may be required for control of Pythium and Phytophthora zoospores (Cayanan et al., 2009; Hong and Richardson, 2004; Hong et al., 2003; Lang et al., 2008), it may be difficult to achieve that level of free $\mathrm{Cl}$ without more than 10 times the applied $\mathrm{Cl}$ concentration. We have observed that some growers are indeed applying several times higher chlorine concentrations than $2 \mathrm{mg} \cdot \mathrm{L}^{-1}$ $\mathrm{Cl}$ when trying to control dosage based on a free $\mathrm{Cl}$ target while also injecting watersoluble fertilizer that contains ammonium. The implications in terms of phytotoxicity risk and pathogen control of that practice are unknown, and chlorination cost would increase.

An alternative sanitizing technology other than $\mathrm{Cl}$ could be used that is more compatible with water-soluble fertilizer, for example $\mathrm{Cl}$ dioxide. Copes et al. (2004) found the efficacy of $\mathrm{Cl}$ dioxide in nutrient solutions for control of Fusarium oxysporum was more affected by $\mathrm{pH}$ and micronutrients than $\mathrm{N}$, and $\mathrm{Cl}$ dioxide at $2 \mathrm{mg} \cdot \mathrm{L}^{-1}$ was able to provide $50 \%$ decrease of $F$. oxysporum in nutrient solutions that contained $100 \mathrm{mg} \cdot \mathrm{L}^{-1} \mathrm{~N}$ and $3 \mathrm{mg} \cdot \mathrm{L}^{-1}$ of micronutrients (copper, iron, manganese, and zinc).

Our results emphasize the need for monitoring of chlorine levels and ORP in horticulture applications, where $\mathrm{N}$ and other contaminants create a $\mathrm{Cl}$ demand that is likely to vary over time, thereby affecting residual free $\mathrm{Cl}$ concentration. Research conducted by Lang et al. (2008) demonstrated that free $\mathrm{Cl}$ concentration and ORP were important for

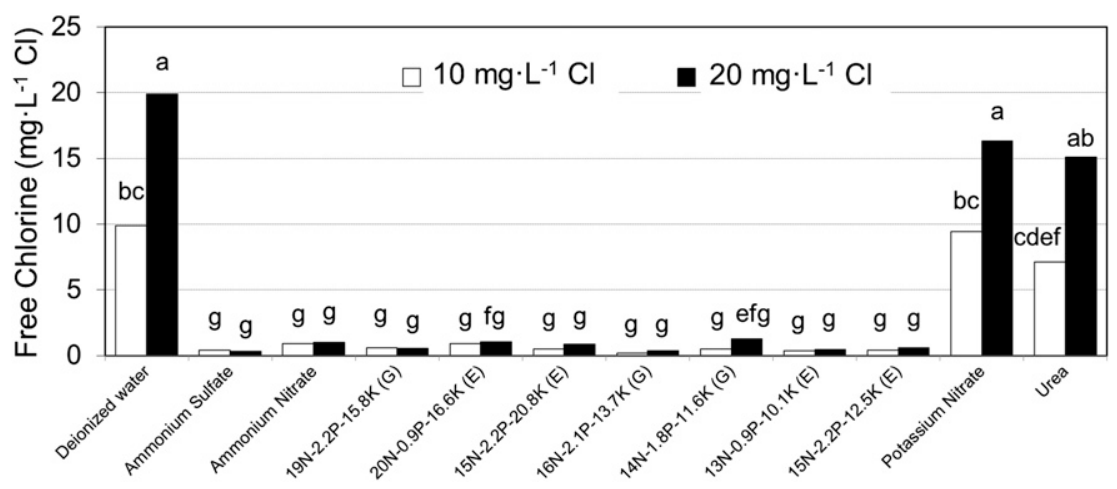

Fig. 3. Effect of sodium hypochlorite at $10 \mathrm{mg} \cdot \mathrm{L}^{-1}$ chlorine $(\mathrm{Cl})$ and $20 \mathrm{mg} \cdot \mathrm{L}^{-1} \mathrm{Cl}$ measured after $2 \mathrm{~min}$ in 11 nutrient solutions at $200 \mathrm{mg} \cdot \mathrm{L}^{-1}$ nitrogen $(\mathrm{N})$ and a deionized control in Expt. 3 high applied $\mathrm{Cl}$. Letters represent mean comparisons using Tukey's honestly significant difference at the $P=0.05$ level, $\mathrm{n}=2$ replicates. disinfestation of Pythium aphanidermatum. Measurements of $\mathrm{pH}$, free $\mathrm{Cl}$ concentration, and ORP are standard operating procedures to monitor to ensure treatment efficacy in water and wastewater treatment facilities (EPA, 1999), and these procedures should be adapted to horticulture operations.

\section{Conclusions}

The low level of free $\mathrm{Cl}$ found in these experiments when combined with fertilizers that contained ammonium indicate that hypochlorous acid is likely to be rapidly converted to complexed $\mathrm{Cl}$ forms when water-soluble fertilizers containing ammonium are used in combination with $\mathrm{Cl}$. Urea also reacted with hypochlorous acid, although our results showed inconsistency in colorimetric measurement of free vs. total $\mathrm{Cl}$ in urea solution. Urea undergoes multiple $\mathrm{N}$-chlorination steps that occur over a period of hours at 20 to $30{ }^{\circ} \mathrm{C}$ (Blatchley and Cheng, 2010). In contrast, free $\mathrm{Cl}$ was not decreased by nitrate $\mathrm{N}$.

Several alternative strategies may avoid $\mathrm{N}$ reactions with $\mathrm{Cl}$, including use of solid fertilizers, injecting $\mathrm{Cl}$ in a holding tank before fertilizer injection, using nitrate-based watersoluble fertilizer, or possibly using injecting urea and $\mathrm{Cl}$ with a short contact time. Monitoring is essential with $\mathrm{Cl}$ and any other water treatment technology with important parameters including solution $\mathrm{pH}$, active ingredient levels of the sanitizing agent, ORP (if oxidizers are used), the density of colonyforming units of indicator organisms such as aerobic bacteria plate counts, and the presence or absence of particular pathogenic organisms of concern.

Research is needed on the efficacy of chloramines for controlling plant pathogens in horticulture. Chloramines have greater stability than hypochlorous acid, which results in increased residual activity for applications such as biofilm control in irrigation lines (LeChevallier et al., 1988) but requires a longer contact time to control bacteria (Degreìmont, 1979). Unlike hypochlorous acid, chloramines do not form carcinogenic trihalomethanes (Degreimont, 1979), although trichloramine $\left(\mathrm{NCl}_{3}\right.$, a byproduct of urea and hypochlorous acid) is a respiratory and skin irritant (Blatchley and Cheng, 2010). Chloramines caused root necrosis in hydroponic lettuce when a low hypochlorous acid concentration $\left(0.3 \mathrm{mg} \cdot \mathrm{L}^{-1} \mathrm{Cl}\right)$ was combined with $9.4 \mathrm{mg} \cdot \mathrm{L}^{-1}$ of ammonium $\mathrm{N}$ (Date et al., 2004). More information is clearly needed to determine the implications of the common practice of dual injection of fertilizer and $\mathrm{Cl}$ in horticulture.

\section{Literature Cited}

Akin, E.W., J.C. Hoff, and E.C. Lippy. 1982 Waterborne outbreak control which disinfectant? Environ. Health Perspect. 46:7-12.

American Public Health Association. 1995. Standard methods for the evaluation of water and wastewater. 18th Ed. Amer. Public Health Assn., Denver, CO 
American Water Works Association. 1991. Guidance manual for compliance with the filtration and disinfection requirements for public works systems using surface water sources. U.S. Environmental Protection Agency, Office of Groundwater and Drinking Water, Washington, DC.

Blatchley, E.R. and M. Cheng. 2010. Reaction mechanism for chlorination of urea. Environ. Sci. Technol. 44:8529-8534.

Cayanan, D.F., P. Zhang, W. Liu, M. Dixon, and Y. Zheng. 2009. Efficacy of chlorine in controlling five common plant pathogens. HortScience 44: 157-163.

Copes, W.E., G.A. Chastaganer, and R.L. Hummel. 2004. Activity of chlorine dioxide in a solution of ions and $\mathrm{pH}$ against Thielaviopsis basicola and Fusarium oxysporum. Plant Dis. 88:188-194.

Date, S., S. Terabayashi, Y. Kobayashi, and Y. Fujime. 2004. Effects of chloramines concentration in nutrient solution and exposure time on plant growth in hydroponically cultured lettuce. Sci. Hort. 103:257-266.
Degreimont, S.A. 1979. Water treatment handbook. Halsted Press, New York, NY.

Environmental Protection Agency. 1999. Guidance manual for alternative disinfectants and oxidants. Environ. Protection Agency, Office of Groundwater and Drinking Water, Washington, DC. 12 Nov. 2012. <http://water.epa.gov/ lawsregs/rulesregs/sdwa/mdbp/upload/2001 01_12_mdbp_alter_chapt_6.pdf >.

Hong, C.X. and P.A. Richardson. 2004. Efficacy of chlorine on Pythium pathogens in irrigation water. Proc. S. Nursery Assn. Rsch. Conf. 49: 265-267.

Hong, C.X., P.A. Richardson, P. Kong, and E.A. Bush. 2003. Efficacy of chlorine on multiple species of Phytophthora in recycled nursery irrigation water. Plant Dis. 87:11831189.

Lang, J. M., B. Rebits, S.E. Newman, and N. Tisserat. 2008. Monitoring mortality of Pythium zoospores in chlorinated water using oxidation reduction potential. Plant Health Progress. Bul. 0922.
LeChevallier, M.W., C.D. Cawthon, and R.G. Lee. 1988. Inactivation of biofilm bacteria. Appl. Environ. Microbiol. 54:2492-2499.

Morris, J.C. 1966. The acid ionization constant of hypochlorous acid from 5 to $35^{\circ} \mathrm{C}$. J. Phys. Chem. 70:3798-3805.

Stewart, M.H. and B.H. Olson. 1996. Bacterial resistance to potable water disinfectants, modeling disease transmission and its prevention by detection. Cambridge U. Press, Cambridge, UK. p. 140-142.

Suslow, T.V. 2004. Oxidation-reduction potential for water disinfection monitoring, control, and documentation. U. of California, Div. Ag. Nat. Res. Bul. 8149.

White, G.C. 1992. Handbook of chlorination and alternative disinfectants. $3^{\text {rd }} \mathrm{Ed}$. Van Nostrand Reinhold Co., New York, NY.

Yu, R.F., H.W. Chen, W.P. Cheng, and Y.C. Shen. 2008. Dynamic control of disinfection for wastewater reuse applying $\mathrm{ORP} / \mathrm{pH}$ monitoring and artificial networks. Resour. Conserv. Recycling 52:1015-1021. 